\title{
BIG DATA-DRIVEN EARLY ALERT SYSTEMS AS MEANS OF ENHANCING UNIVERSITY STUDENT RETENTION AND SUCCESS
}

\author{
N. Cele \\ Institutional Planning \\ University of Zululand \\ Richards Bay, South Africa \\ e-mail: CeleNHL@unizulu.ac.za / https://orcid.org/0000-0003-3689-7385
}

\section{ABSTRACT}

This article argues for the establishment of big data early alert systems that inform data-driven student support mechanisms in universities. It proposes a guiding framework for integrated big data to enhance student success premised on a comprehensive understanding of students as people in the world who arrive at universities with various complex life problems that may disrupt their learning opportunities. It argues that various data components should be linked together to foster coherence and seamlessness in understanding student socio-economic and academic needs to develop responsive learning-enhancement intervention programmes. This is based on action research conducted through projects launched at the University of Witwatersrand in 2015 and at the University of Zululand in 2018. The systems were launched, and data was collected using the proposed student performance tracking system. This article explores conceptual and theoretical underpinnings of establishing big data-based student support systems in South African universities. A big student data model is proposed for wider use in South African universities.

Keywords: big data, data analytics, student performance, student success, undergraduate student experience, responsive academic support, graduate attributes, first year experience, student retention, graduateness.

\section{INTRODUCTION}

If universities are to understand student attrition and promote retention and success, student support systems have to be informed by an array of data sets derived from various sources with the view to understand students as people in the world. Early alert systems are not merely designed to ensure value for money in the case where students are viewed as consumers but are robust public good instruments that can be used to widen the understanding of students' needs and multiple factors that affect and shape their learning experiences and successes. Universities in South Africa and elsewhere in the world aspire to be vaunted for creating student-centred, intellectually vibrant, socially embracing and culturally diverse teaching and learning environments for their incumbent students. "Responsiveness" and "student-centeredness" have become new buzz words in higher education, as various institutions seek to identify factors that 
define a distinct experience for their students.

\section{UNIVERSITIES AND THE MODERN PUBLIC GOOD MANDATE}

Student retention and success remain one of the widely studied aspects of higher education (Tinto 2006). Spady (1970) proposed five variables (academic potential, normative congruence, intellectual development, grade performance and friendship support) framework as factors that contribute to student retention and success. Building on to this, Tinto (1975) argued that student success and retention was determined by both formal and informal university experiences and social integration. As early as the 1980s, Bean (1980) advanced that student success and retention was influenced by background characteristics such as prior academic experience and performance, socio-economic status and distance from home. The understanding led to the shift of focus of student retention to student under-preparedness (Demetriou and Schmitz-Sciborski 2012). In this context, Anderson and McGuire (1997) advocated for academic advising which kept students motivated as an imperative for student retention and success. Most recently, crossdepartmental interaction (Habley 2004; White 2005; Swail 2004) and academic development programmes have been held as an article of faith for student success and retention in universities. Through these various phases of student success and retention theory development, it emerged that external non-academic factors played a significant role in shaping student success and retention. The notion that a university is as an institution solely preoccupied with the pursuit of reason centred on autonomy and the ability to reflect "upon a world of determinations from which it is liberated as a pure point of consciousness" (Readings 1996) is gradually being neutralised by modern public good imperatives. Just like research excellence, student success has taken a centre stage in university business. No university wants to be known for neglecting the needs of its students merely because it believes that it is a sovereign entity above science, societal needs and political imperatives of any given social order, pre-occupied with scientific curiosity as the only means of the intellectual capital generation (Cele, Bhengu, and Mbhele 2007).

In recent years, it has strongly emerged that university practices based on the "ivory tower" model advance social exclusion and undermine the public good mandate of public universities. As a consequence, universities are increasingly keen to respond to student experiences and success imperatives by providing interventions and facilities that are sensitive to student needs. There is ongoing research done on the use of innovative pedagogies to enhance student success. In this article student success is defined as retention (persistence), module success completion (academic achievement), progression (student advancement), attainment of graduate attributes (holistic development) and timeous completion of studies which leads to 
graduation (educational attainment). Cuseo (2007) argues that promoting student success requires a comprehensive approach that goes beyond the confines of academic or intellectual dimension of student development to address student needs in a holistic manner as people in the world.

Relying on pre-admission selections tests traditionally used to attract new students with sufficient academic ability and predict student academic achievement is now being questioned as a form of social exclusion especially in South African higher education. These entrance test scores that were sufficient to predict student success and the length of the study (Ningrum and Ekayani 2019) are no longer the universal articles of faith. The use of test scores provides limited space to use other forms of background data to analyse peculiar student needs and circumstances shaping the teaching and learning experience. Many universities have even put in place early-warning systems to "alert students and their campus support agents to issues impacting on academic performance" (Faulconer et al. 2013). The notion that high drop-out and failure rates serve as proxies for high academic standards and inaccessibility of science has lost relevance in modern society. Increasingly it is understood that attrition can be influenced by the social, environmental factors, academic backgrounds, various other out-of-class learning factors, and student characteristics (Ratcliff 1991; Wessel et al. 2009). Even traditional advocates of selection tests in medical schools who have always argued for the use of admission tests as filters to select-in students who stand the chance to succeed (Al Alwan et al. 2013) and select-out the underprepared are beginning to change their views. General pre-admission tests that were used as a diagnostic benchmark to predict student academic performance at an entrylevel do not fully explain the student potential without factoring in various academic and nonacademic factors that shape student performance (Wadee and Cliff 2016).

Schwartz and Washington (1999) also suggest that, although selection tests became essential elements in university admissions, as tools they add little to predicting the success of students at university. This simply means that universities are forced to imagine new means through which to assess the needs of students using principles of student-centredness. Based on these factors, universities have come to realise that getting students to enrol is only the first step, and proactively supporting them early enough is key to student success (Varney 2012). The public good mandate of a university is not merely derived from the innate reality that it is publicly controlled, state-owned and -funded (Enders and Jongbloed 2007), but it is equally entrenched in the public expectation that a university should generate the intellectual capital that advances knowledge, produces human capital and technology transfer with the view to advance the socio-economic quality of life. This publicly calls for a deliberate means and purpose of these universities to institutionalise student-centred initiatives that enhance students' 
success and quality of life.

\section{WHY UNIVERSITIES NEED INTEGRATED BIG DATA ANALYTICS AND EARLY ALERT SYSTEMS}

Higher education student success challenges are often largely associated with first-year undergraduate studies in the university. Hamblin (1986) defines the first-year experience as "the encounters of the first year of study of an undergraduate student in a higher education institution". He further states that the mere process of becoming a first-year student is one that can be filled with anxiety, fear and uncertainty as the students are venturing into the unknown, especially for those who are first-time first entry tertiary education candidates. Newly admitted undergraduate students often feel confused, tense, threatened, and even helpless. If they do not have innate coping mechanisms, a combination of these factors can lead to early drop-out or failure, depending on the university environment. Varying levels of student preparedness for university education, student home and schooling background, and available support systems for academic and psychological well-being, inform student success. Wilcox, Winn, and FyvieGauld (2005) recommend that an important area of investigation for researchers studying student attrition and retention is to establish reasons why students fail to complete their first year of tertiary education. This is particularly important because the experiences of students in their early days at university serve as a foundation on which the rest of their university experiences may be built (Upcraft and Gardner 1989). Literature shows that various factors contribute to an unpleasant first-year and undergraduate student experience at university. Among these factors, stress is the most prevalent, although it should be noted that not all students who experience stress eventually drop out. Furthermore, what one student might perceive as stressful may not necessarily be stressful to another (Barnsley 1992). Circumstances and background factors on individual students should be understood through data collection and individual learner profiling to assist universities in developing bespoke interventions centred on student needs. Such data gives impetus to enhanced understanding of student needs which creates personal validation of students and brings about self-efficacy, social integration, self-awareness, personal meaning, sense of purpose and belonging, self-reflection, and active involvement of students in their learning careers (Cuseo 2007).

Greenberg (1981) argues that living away from home for the first time, having to manage one's own finances, establishing new friends, and generally assuming greater responsibility for oneself can be overwhelming for undergraduate students. The transition from high school to the first year of the university also requires an array of academic, social, and emotional coping tools (Wilkie and Kuckuck 1989). There is an articulated view that first-year students often 
arrive at university uncertain of the standard of work that will be expected of them. This is often complicated by varying levels of readiness for university education and often compounded by student family and schooling backgrounds. The transition from rural to urban environments, factors of social-class and the inability to adapt to this new environment often causes students to withdraw from the university during or after their first year, or to perform at a lower academic level than they are capable of (Tinto 1982).

Most students (30\%) who drop out during their first year of study, do so without passing any course, suggesting that they drop out largely before the commencement of the second term (Moodley and Singh 2015). Cohort analysis data in the South African higher education system suggests that the majority of students may be delayed (stay in the system longer than the minimum duration of their study time) (DHET 2012; CHE 2010; 2018; 2017). Very few students drop out during their 2nd, 3rd or 4th years of study. However, if they survive the first year of study, most eventually they graduate. Various student support initiatives have been put in place for student development in various institutions including first-year experience programmes, tutorials, foundation provisioning and student residence development programmes. While some of these contribute to improved student performance, the most focus on the academic content and do not take into consideration socio-environmental factors that often affect the academic performance of students (Moodley and Singh 2015). Various studies have previously suggested that student performance can be influenced by the social and academic backgrounds of students, student characteristics, environmental factors and family factors (Ratcliff 1991). Belch (2004) argues that belonging, sense of purpose, self-determination apparent disabilities, non-apparent personal conditions and involvement are other important factors influencing students with. Wessel et al. (2009) call this approaching retention from an ecosystems perspective with the view to minimise barriers to students' success. Moodley and Singh (2015) call these socio-cultural, structural, policy, institutional, personal and learning factors. The analysis of student enrolment data across various universities in South Africa shows that universities do not have access to such additional data that widely profile students as people in the world, and whose academic performance is influenced by an array of external factors external to the immediate university environment. Various data-driven undergraduate student-support mechanisms and systems have to be put in place to mitigate the risks that students face, especially first-year students. This article presents a data framework that should shape the collection of such student data which through data interconnectedness present an opportunity for a contextual understanding of student performance challenges. Such data sets also present an opportunity for predictive analytics that would help universities develop responsive interventions to student performance challenges as opposed to traditional 
student support programmes that are often fixated at fixing the curriculum or fixing a student as an under-performer.

There are two main benefits sought from implementing the system of understanding students' personal background, tracking course performance scores, understanding student behavioural patterns through learning analytics and cohort analysis. The first reason is that of ensuring that students are received as people in the world with particular socio-economic background factors shaping their behaviour at universities. Understanding this imperative is essential for ensuring that teaching and learning are aligned to a precise student context, not an abstract ivory tower pedagogical intervention. The second benefit is that of improving the academic performance of students in terms of course pass rates, throughputs and graduations. The combination of the cohort analysis, tracking of students at risk, and identification of courses with a high failure rate will provide the basis for designing interventions to clear the blockages caused by the courses with a high failure rate, assisting students at risk and appropriate student enrolment planning. This is intended to yield improved pass rates, throughput rates and graduations, as well as reduce drop-out rates.

\section{THE NEED FOR COMPREHENSIVE INTERVENTIONS TO STUDENT SUPPORT}

The common purpose of developing academic and student support strategies should be that of substantially improving student completion rates while maintaining wider access and quality teaching and learning. Student support should respond to different kinds of barriers which are both cognitive- academic deficiencies and non-cognitive life experiences that could potentially delay progression and academic success. These interventions should be comprehensive and include consultation time with lecturers, e-learning support, peer-led engagements, tutorials, one-to-one advising, counselling, mentoring and involvement of students in the design of interventions. Universities should expand from providing generic interventions to developing personalised interventions that deal with real-life issues affecting students. Non-academic issues include hunger and poverty, medical factors, students' prior learning experience, grade information, parental education, cultural-ethnicity, socio-economic conditions, race and gender. The collection of such data during first-time first year registration through a biographical questionnaire helps universities understand external factors that influence student performance.

Currently, there are two universities in South Africa that have implemented the biographical data collection system during first-time registration of undergraduate students, and these are the University of the Witwatersrand where the tool was introduced in 2015 and the University of Zululand where the tool was introduced in 2018. It is important to harness the wealth of information collected through the biographic questionnaire with the view gain 
valuable insights to assist educators to improve the quality of teaching. When such data is used to develop responsive interventions, students feel validated and involved in their own academic development (Peters and Daly 2013). Catalysing the processes of learning for individuals and collective feedback is considered one of the most powerful tools in enhancing the learning experience (Harrison and Rodriguez-Dehmer 2013). The opportunity to deeply engage with role models, professors, graduate students, tutors or more advanced peers, allows students an opportunity to identify similarities in their backgrounds.

\section{DATA-DRIVEN INTERVENTIONS AND STUDENT-CENTEREDNESS}

Understanding university readiness among undergraduate students by developing a systematic analysis of biographic data on student home and school background, using existing school profiling and performance data, and collecting more detailed student information on registration are the primary strengths of any university. Universities in South Africa are beginning to realise that data analytics is widely used around the world by organisations seeking to identify datadriven solutions to their problems (Henry and Venkatraman 2015). Data analytics helps generate models that can predict future patterns and trends, thus helping universities develop generic, shared, responsive solutions while allowing space for the creation of particular forms of differentiated interventions. Student-centeredness is an expanded view of educational purposes that extends beyond an Instrumentalist orientation which aims at information transfer and skills development for the purpose of a job role; it also extends through a liberal purpose of reaching one's potential and making meaning; to a transformative purpose that includes community and personal development and engagement, critique and action.

Most studies done on student support tend to focus mainly on teachers, knowledge content and pedagogical interventions (Elen et al. 2007) or module scores to find solutions to student learning challenges (Wadee and Cliff 2016). The challenge with isolated student grades-linked data analytics is that it often leads to interventions that come too late in the learning process, designed to look for solutions to fix the student's cognitive skills, the curriculum or the environment. Such interventions hardly look at means to fix pedagogies, contextualisation of curriculum, those who teach or student support interventions. This approach demonstrates a limited understanding that student performance can be affected by socio-economic factors, cultural exposure, social class and a variety of other factors including home and family background and values.

While student-centeredness has been largely defined in relation to the distribution of knowledge through problem-solving and student-directed engagements, data-driven student support is a much more personalised form of student-centeredness. Data-driven student support 
encourages putting in place modalities and interventions that enhance the provision of differentiated learning opportunities and environments based on the actual needs of students and their levels of readiness. Figure 1 presents a framework that identifies various sources and forms of data that should be used to understand peculiar contextual needs and life experiences that shape the way students engage with learning opportunities at university. To do this requires knowing students beyond academic performance scores, having flexible programmes and interventions, and eliciting the students' perspectives. The influence of individualised interventions shifts the focus from blaming students, to holding institutions accountable for student outcomes.

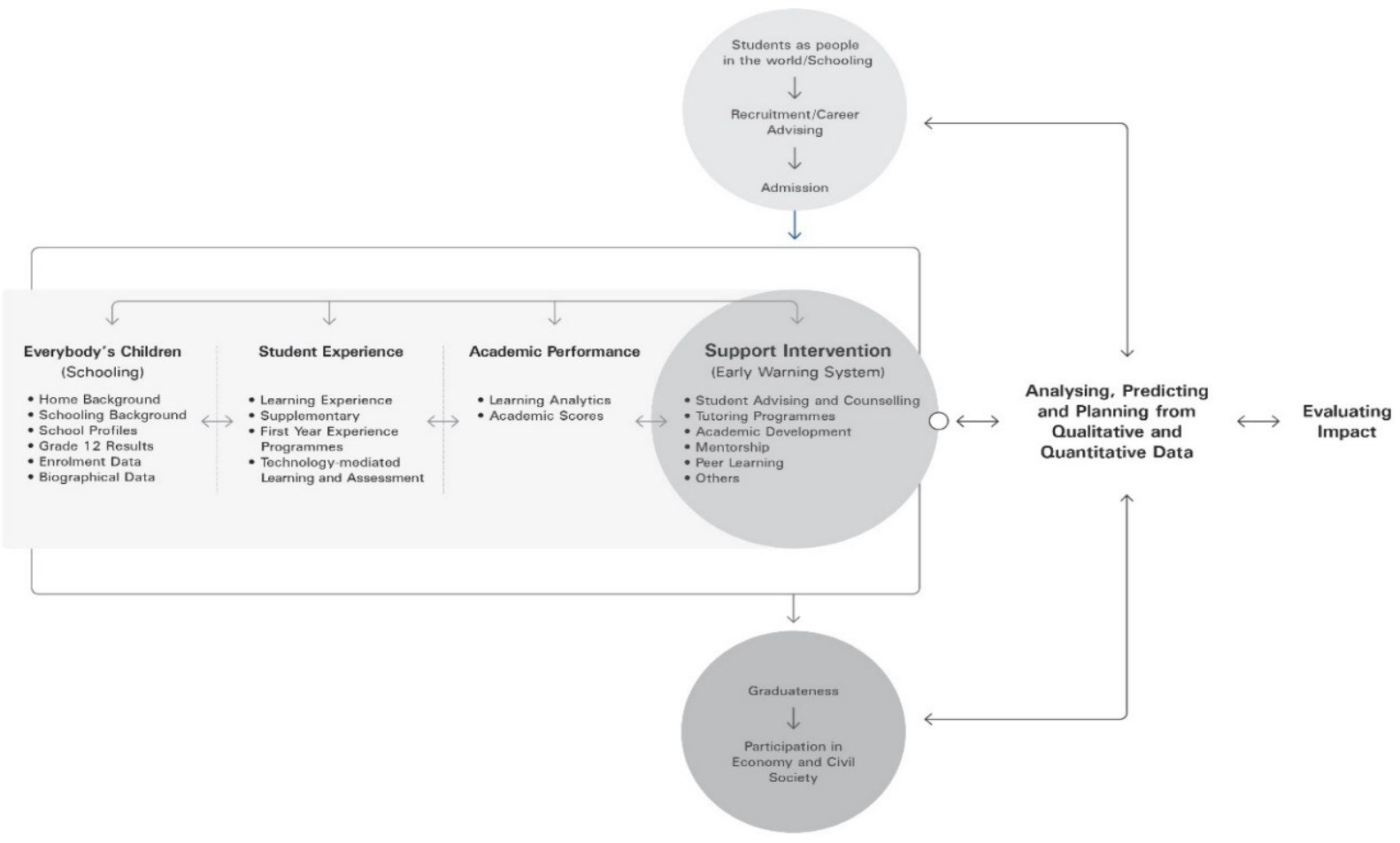

Figure 1: Big data integration framework for data-driven student profiling and performance tracking

\section{THE USE OF INTEGRATED BIG DATA TO DEVELOP STUDENT SUPPORT AND ENHANCE THE SUCCESS}

Judd, McClelland, and Ryan (2011) argue that there are various ethical and legally sound ways of using descriptive data collected from students. Integrated data analytics provides that context. First, integrated big data analytics can be used to identify patterns and trends that can predict student success. Secondly, it can be used to identify prevailing challenges that prevent successful learning. And thirdly, it can be used to design and institutionalise intervention mechanisms and academic opportunities for student success. While Rubel and Jones (2016) 
argue that there is no justification why universities should not use learning analytics to intervene when students are performing poorly, there are legitimate concerns about data analytics and learning analytics that have to be addressed.

Although academic success can be measured in various ways, two of the highest profile objective measures are performance on tests and examinations, as well as graduation rates.

There is a widely shared view that learning analytics is a useful instrument for improving the quality of learning and prospects of student success (James et al. 2018; Avella et al. 2016; Picciano 2012). However, there are fundamental questions that need to be addressed and these relate to:

- $\quad$ privacy of student information;

- the intrusive nature of the manner in which data is collected;

- the power that institutions have over the students, about whom data is collected, who often have no recourse;

- classification of individuals on the basis of socio-economic status, gender, ethnicity and race, thus reinforcing old prejudices;

- monitoring student movement and behaviour to make predictive projections about their academic performance;

- $\quad$ using data to place students' inboxes and possibly stereotype them.

Setting up data collection systems and getting student consent at the point of data collection, will help address these factors by ensuring that data analysis does not lead to any form of negative profiling and social exclusion. In some instances, the analysis of such data may need to be aggregated to ensure that generic programmes that address the needs of students with similar needs are collectively addressed. Eventually, there will be particular instances where bespoke interventions are developed for individual students. Big data analytics can be used to benefit university and students by:

- $\quad$ introducing evidence-based decision making and use of resources;

- providing informed insights into student readiness, teaching arrangements and their effectiveness;

- $\quad$ increasing efficiency and organisational productivity;

- $\quad$ advancing transparency of understanding student needs;

- enhancing high-level comparison and networking;

- $\quad$ providing predictive models for behaviour and performance; 
- $\quad$ enhancing holistic responsiveness to teaching and learning challenges.

(Picciano 2012; Avella et al. 2016)

Promoting institutionalisation of integrated big data analytics provides links to behavioural, personal identity and learning footprints data of individual students. The key components of such a learning track are the schooling background data, home background data, grade twelve results, enrolment data, engagement survey data, academic performance data, learning analytics and use of services data, pedagogical data, mentoring data, communities of practice data and graduation data as shown in Figure 1 (James et al. 2018; Avella et al. 2016; Picciano 2012; Moodley and Singh 2015).

\section{BIOGRAPHIC PROFILES, STUDENT SUPPORT, STUDENT RETENTION AND SUCCESS, AND GRADUATENESS}

Big data integration analytics encourages the collection of data from various sources. In the case of student data, it includes collection of biographical data about home and family background, schooling background, quintile state and classification of feeder schools, grade twelve performance results, university admission scores, enrolment data, student engagement data, learning analytics data, class performance data, module performance data, lecturer feedback data, student support and development data (Chessell 2014). However, the glaring challenge in big data integration analytics remains that of legal imperatives and ethical considerations of knowing and understanding how descriptive data about students can be stored with reasonable privacy and not be used to stereotype and judge students (Henry and Venkatraman 2015).

Castells (2001) argues that responsiveness to student needs by a $21^{\text {st }}$ century university has largely been informed by a customer-focused approach to higher education which has seen university branding increasingly shaping what is happening inside institutions, learning programmes and individual classrooms. He maintains that commodification of higher education (product) has transformed universities to knowledge malls (marketplace) and deformed academic provision as an economic enterprise (demand and supply). While value for money imperatives could be part of the driving force to transform universities, it could be equally argued that one of the contributing factors is commitment to define the moral purpose through fitness for purpose. Studies done on graduateness suggest that grooming of graduates through quality education and coordinated support (Archer and Davison 2008; Curry, Sherry, and Tunney 2003; Higgins 2008; Van Lill 2006; Harvey 1993) can enhance the development of globally transferable competences (Curry, Sherry, and Tunney 2003). If graduateness is defined 
beyond acquisition of generic, core and transferable skills for employability, and is seen as intellectual development (Steur, Jansen, and Hofman 2012), then it is important for universities to develop a comprehensive understanding of students and their contextual realities. Intellectual development implies transformation within an individual which shifts values, and beliefs: a formative function of a university which contributes to the student's personal growth (Jansen 2009). If universities have to cultivate (Steur, Jansen, and Hofman 2012) domains of graduateness like scholarship, reflective thinking and moral citizenship, then student support interventions cannot be derived from module scores only. A more detailed collection of data is required that maps the student learning pathway from pre-reflective thinking, quasi-reflective thinking and reflective thinking stages (King and Kitchener 2004). Higher education in South Africa is increasingly motivated by the demand and supply realities of both graduates and employers. This leads to universities operating like industries seeking to innovate their core services and products (in this case teaching and learning) to produce highly employable graduates (Lie, Pang, and Mansur 2009) and members of civil society. Employability, or an individual's capability to gain initial employment, maintain it and seek new employment if desired (Lie et al. 2009), is often seen as a part of national prosperity in industrialised, communities and knowledge economy states (Brown et al. 2008).

Employer opinions on graduates and attributes needed for success in the workplace have become increasingly vital with the rise of the knowledge economy entrenched in globalisation and its effect on higher education provisioning (Lie et al. 2009). Graduate attributes, which form part of the requisite skills, knowledge competence and values, are shaped by the quality of the student experience distributed through a university environment as well as the philosophical underpinnings of teaching and learning, and student support. Beyond the contractual duty to provide education, it is the moral and public good duty of universities to provide well-coordinated interventions that nurture and produce the envisaged state of graduateness. This expectation does not take away the obligation of employers to develop their workforce's needs to a range of personal and intellectual attributes beyond those traditionally made explicit in Higher Education Initiatives (Lie et al. 2009).

Collecting student biographic data helps link the personal, biographical data for each student with the information about the type and profile of the school from which they come from, their family's socio-economic status, their level of readiness for university education and the enrolment information contained in the student information system. In addition to this personal background data, the university will gradually acquire a learning analytics footprint. It is envisaged that accumulative collection of student performance details will link directly to these biographic categories of data. This would enable the university to conduct proper analysis 
which would lead to better understanding of who their students are and what forms of interventions they need to help them through their studies.

While using pedagogies that embrace the creation of student-directed learning environments; co-designing learning environments; and differentiating learning environments; student data-driven student support aims at collecting biographic data to enrich student profiling. This is done by linking patterns of learning analytics and student performance with the understanding of student background that shapes ways in which the students respond to learning challenges. While it has been repeatedly argued that in a journey of life, where you come from is not a direct determinant of your destination, students' life experiences shape the way in which they engage with the world, including learning. It is critical for data-based student profiling not to be construed as part of negative profiling and the creation of segregated interventions for students of particular socio-economic backgrounds. It is important to note that even in institutions with largely homogenous social backgrounds, differentiated interventions may still be solicited for a nuanced understanding of student backgrounds and needs. It is analytics informed by a big data approach to profiling students with the view of understanding the trends and patterns of their academic performance, that help universities make informed decisions about student support interventions. Student support interventions can no longer be designed solely based on student performance in first tests, or the educator's skills, biases, past experiences, intuition, innate cognitive insight, or stereotypes. Big data analytics is the tool for data-driven solutions to student learning challenges.

The big data analytics provide a comprehensive picture of various student background variables including: the location, type and financial standing as well as the facilities of the schools from which they graduated; and the students' home background including financial income, family structure, and educational background of family members. It is believed that in the South African context, such socio-economic variables often define advantage (ness) - which often manifests itself in a racial and class differential in student performance at universities.

In a socio-economically stratified schooling system like South Africa, understanding profiles and quality arrangements in these feeder schools help universities understand the state of university-readiness of their undergraduate students. Schools are classified in a quintile continuum where Quintile One represents the impecunious and most under-resourced, and Quintile Five, the highly resourced. However, Quintile Six has been created in the South African system to represent the extremely highly resourced - usually private - schools. Social class, poverty and hunger play a pivotal role in the success of students. Financial hardships could distract students, affect their performance and result in drop-outs. This is supported by literature which reveals that the socio-economic status of first-year students is a valuable 
predictor of timely completion of studies (Letseka and Breier 2008). A study conducted on student poverty in higher education in South Africa revealed that students from stable socioeconomic backgrounds are more likely to complete a bachelor's degree within four years $(n+1)$ as opposed to to students who do not come from privileged family backgrounds.

Some have argued that the "staying power" factor (students having sufficient motivation and morale) often defines whether or not students hang on until they graduate (Moleli 2005). Wasonga, Christman, and Kilmer (2003) observed that first-year students who began their studies with a commitment to completing their degrees are more likely to persist than those with wavering or uncertain commitment. Commitment usually correlates with students' levels of confidence about their ability to learn and succeed. While student support mechanisms are essential to provide a sustainable and enduring learning experience for undergraduate students, most of these are often not informed by big data analytics and an understanding of students (Johnson 2005). There is a widely shared consensus that student support mechanisms help undergraduate students become resilient and overcome academic difficulties and develop skills to cope with academic life (Wasonga, Christman, and Kilmer 2003). The challenge with these interventions is that they are often derived from perceived students' needs and hardly informed by an extensive biographic profile of these students.

\section{CONCLUSION}

Universities need to put in place big-data analytics systems to strengthen learning and teaching practices, taking into account significant developments in higher education, including the need for institutional responsiveness to the learning needs of students. The imperative to provide quality education that meets the needs of diverse students, calls for the data-based reimagination of student support interventions in a way that promotes student engagement and public good. Universities have entered into a phase where they are expected to place studentcenteredness at the heart of teaching and learning by providing academic and social support; enhancing the quality of learning and teaching; and improving student performance, throughput and graduation rates. None of these aspirations can be achieved if a university continues to ignore important information and factors about students. The collection of biographical information helps reveal if students came from privileged or disenfranchised family, home or school backgrounds. Universities have to develop data collection systems to ensure that student intervention programmes are largely informed by a collective understanding of real factors that shape student experiences and how they engage with academic opportunities. It is when such forms of data are used to design support interventions that students gain personal validation, develop self-efficacy, a sense of purpose and belonging, self-reflect, get socially integrated, 
become self-aware and become actively involved in their learning (Cuseo 2007). Involvement motivates them to remain engaged and successful in their studies.

\section{REFERENCES}

Al Alwan, I., M. Al Kushi, H. Tamim, M. Magzoub, and M. Elzubeir. 2013. "Health Sciences and Medical College Preadmission Criteria and Prediction of In-Course Academic Performance: A Longitudinal Cohort Study." Advances in Health Sciences Education 18(3): 427-438. https://doi.org/10.1007/s10459-012-9380-1.

Anderson, Edward C. and W. McGuire. 1997. Academic Advising for Student Success and Retention: An Advising Perspective, 32-45. USA Group Noel-Levitz, Iowa City, Iowa

Archer, Will and Jess Davison. 2008. Graduate Employability: What Do Employers Think and Want. The Council for Industry and Higher Education, London.

Avella, John T., Mansureh Kebritchi, Sandra G. Nunn, and Therese Kanai. 2016. "Learning Analytics Methods, Benefits, and Challenges in Higher Education: A Systematic Literature Review." Online Learning 20(2): 13-29.

Barnsley, S. 1992. "Thoughts on the Psychological Processes Underlying Difficulties Commonly Experienced by African Science Students at University." In Proceedings of the 7th Conference of the South African Association for Academic Development, 3-5. Port Elizabeth Technikon Port Elizabeth.

Bean, John P. 1980. "Dropouts and Turnover: The Synthesis and Test of a Causal Model of Student Attrition." Research in Higher Education 12(2): 155-87. https://doi.org/10.1007/BF00976194.

Belch, Holley A. 2004. "Retention and Students with Disabilities." Journal of College Student Retention: Research, Theory \& Practice 6(1): 3-22. https://doi.org/10.2190/MC5A-DHRV1GHM-NOCD.

Brown, Phillip, Hugh Lauder, David Ashton, Wang Yingje, and Stéphan Vincent-Lancrin. 2008. "Education, Globalisation and the Future of the Knowledge Economy." European Educational Research Journal 7(2): 131-156. https://doi.org/10.2304/eerj.2008.7.2.131.

Castells, Manuel. 2001. "Universities as Dynamic Systems of Contradictory Functions." Challenges of Globalisation: South African Debates with Manuel Castells, 206-223. Cape Town: Maskew Miller Longman.

Cele, Nhlanhla, T. Bhengu, and B. Mbhele. 2007. "Higher Education and the Notion of Institutional Autonomy and Academic Freedom." Curriculum Monograph. UNISA.

CHE see Council on Higher Education.

Council on Higher Education. 2010. Access and Throughput in South African Higher Education: Three Case Studies. Council on Higher Education.

Council on Higher Education. 2017. "Vital Stats: Public Higher Education. 2015." Council on Higher Education. (Accessed 30 August 2018).

Council on Higher Education. 2018. "Vital Stats: Public Higher Education." Council on Higher Education. (Accessed 30 August 2018).

Chessell, Mandy. 2014. "Ethics for Big Data and Analytics." IBM. Ibmbigdatahub.Com/Sites/ Default/Files/Whitepapers_reports_file/TCG\%20Study\%20Report.

Curry, Philip, Rhona Sherry, and Orlaith Tunney. 2003. What Transferable Skills Do Employers Look for in Third-Level Graduates? Results of Employer Survey Summary Report. Dublin: University of Dublin Trinity College.

Cuseo, Joe. 2007. "Student Success: Definition, Outcomes, Principles and Practices." In Esource for College Transitions, 1-16. National Resource Center for the First-Year Experience \& Students in Transition, University of South Carolina 
Demetriou, Cynthia Paula and Amy Schmitz-Sciborski. 2012. "Integration, Motivation, Strengths and Optimism: Retention Theories Past, Present and Future." Proceedings of the 7th National Symposium on student retention, 300-312.

Department of Higher Education and Training. 2012. "Green Paper for Post-School Education and Training." Department of Higher Education and Training. https://www.voced.edu.au/ content/ngv:50550.

DHET see Department of Higher Education and Training.

Elen, Jan, Geraldine Clarebout, Rebecca Léonard, and Joost Lowyck. 2007. "Student-Centred and Teacher-Centred Learning Environments: What Students Think." Teaching in Higher Education 12(1): 105-117. https://doi.org/10.1080/13562510601102339.

Enders, Jürgen and Ben Jongbloed. 2007. The Public, the Private and the Good in Higher Education and Research: An Introduction. Public-Private Dynamics in Higher Education. Transcript. https://doi.org/10.14361/9783839407523-001.

Faulconer, Johna, Jayne Geissler, Diane Majewski, and John Trifilo. 2013. "Adoption of an Early-Alert System to Support University Student Success." Delta Kappa Gamma Bulletin 80(2): 45-48.

Greenberg, Jerrold S. 1981. "A Study of Stressors in the College Student Population." Health Education 12(4): 8-12. https://doi.org/10.1080/00970050.1981.10616807.

Habley, W. R. 2004. "The Status of Academic Advising: Findings from the ACT Sixth Annual Survey." National Academic Advising Association Monograph Series 10.

Hamblin, Douglas. 1986. A Pastoral Programme. Wiley-Blackwell.

Harrison, Malou and Isabel Rodriguez-Dehmer. 2013. "Student Affairs and Faculty Join Hands to Support Student Achievement at Miami Dade College." Washington 15(2) (Spring): 12-13.

Harvey, Lee. 1993. Employer Satisfaction: Quality in Higher Education Project. QHE, University of Central England in Birmingham, Birmingham.

Henry, Regina and Santosh Venkatraman. 2015. "Big Data Analytics the Next Big Learning Opportunity." Academy of Information \& Management Sciences Journal 18(2): 17-29.

Higgins, Dr Bonnie. 2008. "Program Evaluation: Utilizing Graduate and Employer Perception Data in Determining Graduates' Job Preparedness Levels.” Journal of Industrial Technology 24(3): 19.

James, Nicole, Vitomir Kovanovic, Ruth Marshall, Srecko Joksimovic, and Abelardo Pardo. 2018. "Examining the Value of Learning Analytics for Supporting Work-Integrated Learning." Australian Collaborative Education Network, 55-61. Australian Collaborative Education Network. National Conference Proceedings.

Jansen, P. J. 2009. "Studenten Leren Niet, Zij Studeren: Over Transformaties Als Psychologische Kern van Hoger Onderwijs [Students Do Not Learn, They Study: About Transformations as Psychological Heart of Higher Education].” Antwerpen: Garant. Groningen University.

Johnson, Bridget Ann. 2005. "Mental Health Promotion in Western Cape Schools: An Exploration of Factors Relating to Risk, Resilience and Health Promotion." PhD Thesis, University of the Western Cape.

Judd, Charles M., Gary H. McClelland, and Carey S. Ryan. 2011. Data Analysis: A Model Comparison Approach. Routledge.

King, Patricia M. and Karen Strohm Kitchener. 2004. "Reflective Judgment: Theory and Research on the Development of Epistemic Assumptions Through Adulthood." Educational Psychologist 39(1): 5-18. https://doi.org/10.1207/s15326985ep3901_2.

Letseka, Moeketsi and Mignonne Breier. 2008. Student Poverty in Higher Education: The Impact of Higher Education Dropout on Poverty, ed. Simeon Maile, 83-262. HSRC Press Repository. South Africa.

Lie, Koo Yew, Vincent Pang, and Fadhil Mansur. 2009. "Employer Perceptions on Graduate Literacies in Higher Education in Relation to the Workplace." English for Specific Purposes World 4(20): $1-15$ 
Moleli, Florence. 2005. "Protective Factors That Could Foster Resilience in First Year Students', University of Western Cape, South Africa.

Moodley, Padhma and Rachael Jesika Singh. 2015. "Addressing Student Dropout Rates at South African Universities.” Alternation Special Edition (17): 91-115.

Ningrum, R. K. and N. W. D. Ekayani. 2019. "Predictive Value of Entrance Test with the Academic Achievement of Medical Students." Journal of Physics: Conference Series, 1402: 022068. IOP Publishing.

Peters, Diane L., and Shanna R. Daly. 2013. "Returning to Graduate School: Expectations of Success, Values of the Degree, and Managing the Costs." Journal of Engineering Education 102(2): 244268.

Picciano, Anthony G. 2012. "The Evolution of Big Data and Learning Analytics in American Higher Education." Journal of Asynchronous Learning Networks 16(3): 9-20.

Ratcliff, J. L. 1991. "Dropout Prevention and At-Risk College Students." Effective Strategies for Dropout Prevention of At-Risk Youth, 251-282.

Readings, Bill. 1996. The University in Ruins. Harvard University Press.

Rubel, Alan, and Kyle M. L. Jones. 2016. "Student Privacy in Learning Analytics: An Information Ethics Perspective." The Information Society 32(2): 143-159.

Schwartz, Robert A., and Charles M. Washington. 1999. "Predicting Academic Success and Retention for African-American Women in College." Journal of College Student Retention: Research, Theory \& Practice 1(2): 177-91. https://doi.org/10.2190/R6GT-NH93-MB0N-TJD2.

Spady, William G. 1970. "Dropouts from Higher Education: An Interdisciplinary Review and Synthesis." Interchange 1(1): 64-85.

Steur, J. M., E. P. W. A. Jansen, and W. H. A. Hofman. 2012. "Graduateness: An Empirical Examination of the Formative Function of University Education." Higher Education 64(6): 861-874. https://doi.org/10.1007/s10734-012-9533-4.

Swail, Watson S. 2004. "The Art of Student Retention: A Handbook for Practitioners and Administrators." In Educational Policy Institute. Texas Higher Education Coordinating Board 20th Annual Recruitment and Retention Conference Austin, TX June, 21: 1-39.

Tinto, Vincent. 1975. "Dropout from Higher Education: A Theoretical Synthesis of Recent Research." Review of Educational Research 45(1): 89-125.

Tinto, Vincent. 1982. "Limits of Theory and Practice in Student Attrition." The Journal of Higher Education 53(6): 687-700. https://doi.org/10.2307/1981525.

Tinto, Vincent. 2006. "Research and Practice of Student Retention: What Next?" Journal of College Student Retention: Research, Theory \& Practice 8(1): 1-19.

Upcraft, M. Lee, and John N. Gardner. 1989. The Freshman Year Experience. Helping Students Survive and Succeed in College. ERIC.

Van Lill, D. 2006. "Grooming Great Graduates." South African Journal of Higher Education 19(5). https://doi.org/10.4314/sajhe.v19i5.25539.

Varney, Jennifer. 2012. "Proactive (Intrusive) Advising".

Wadee, A. A. and A. Cliff. 2016. "Pre-Admission Tests of Learning Potential as Predictors of Academic Success of First-Year Medical Students." South African Journal of Higher Education 30(2): 264278.

Wasonga, Teresa, Dana E. Christman, and Lloyd Kilmer. 2003. "Ethnicity, Gender and Age: Predicting Resilience and Academic Achievement among Urban High School Students." American Secondary Education 32(1): 62-74.

Wessel, Roger D., James A. Jones, Larry Markle, and Curt Westfall. 2009. "Retention and Graduation of Students with Disabilities: Facilitating Student Success." Journal of Postsecondary Education and Disability 21(3): 116-125. 
White, John Wesley. 2005. "Sociolinguistic Challenges to Minority Collegiate Success: Entering the Discourse Community of the College." Journal of College Student Retention: Research, Theory \& Practice 6(4): 369-393.

Wilcox, Paula, Sandra Winn, and Marylynn Fyvie-Gauld. 2005. “It Was Nothing to Do with the University, It Was Just the People': The Role of Social Support in the First-year Experience of Higher Education." Studies in Higher Education 30(6): 707-722. https://oi.org/10.1080/ 03075070500340036.

Wilkie, Carolyn and Sherrill Kuckuck. 1989. "A Longitudinal Study of the Effects of a Freshman Seminar." Journal of the Freshman Year Experience 1(1): 7-16. 